Madrygal. Revista de Estudios Gallegos

ISSN: 1138-9664

\section{Clase de mitoloxía}

Salvador Castro Otero

A Luís Cachafeiro

Unha mañá, Zeus decidiu acabar dunha vez por todas co seu complexo de Edipo. Para ocasión tan especial modificou a súa táctica tradicional. No canto de facerlle as beiras a unha muller fermosa, costume que tantos desgustos lle causara, decidiu saltarse os prolegómenos -ai, os deliciosos prolegómenos!- e agochouse directamente no útero dunha teutoa de nome Pauline.

Acostumado como estaba a camuflarse entre os humanos, non lle resultou demasiado extravagante vir ao mundo como un calquera deles, un día calquera, un mes calquera, un ano calquera... Pauline vivía daquela na cidade de Ulm e, ao ver aquel bichiño, decidiu chamarlle Alberto, se cadra, coa intención de que, nalgún momento, chegase a brillar coma un lóstrego.

Case como chanceándose, como saboreando o futuro por adiantado, Zeus decidiu tomarse a vinganza con calma. Pasou horas en simples e aburridas clases de matemáticas e consumiu xornadas interminables nunha oficina de patentes.

Nestas estaba, alí, na beira do Aar, cando reparou en que había outras maneiras mellores de resolver os problemas co seu pai que o tradicional malo raio te parta!

Algúns din que se agochou no Tártaro, outros que nalgunha illa occidental, mais o único certo é que, cando Crono soubo da Teoría da Relatividade, empezou a perder as forzas, a perder os folgos, a perder a primacía e mesmo a perder a cabeza. Non se sabe moi ben se foi pola dificultade de explicarse a si mesmo, de entenderse a si mesmo, ou pola vertixe de sentirse tan fugaz como a velocidade da luz, á que el sempre considerara o xoguete máis fedello do seu fillo máis tormentoso. 